\title{
Kelola
}

\section{Efikasi Akademik Dan Prokrastinasi Akademik Sebagai Prediktor Prestasi Akademik}

\author{
Zummy Anselmus Dami \\ Bimbingan dan Konseling Universitas Persatuan Guru 1945 NTT \\ zummydami82@gmail.com \\ Paula Alfa Loppies \\ Bimbingan dan Konseling Universitas Persatuan Guru 1945 NTT \\ alfaloppies@gmail.com
}

\begin{abstract}
The purpose of this research is to investigate the relationship between significance or know the academic efficacy and procrastination academic with achievement students academic of project study guidance and counseling, Teaching and Education Faculty University PGRI East Nusa Tenggara. The number of samples used in the study as much as 92 students drawn from population 1180 includes force 2009 as much as much as 102 students 2010 force 205 students, 2011 as much as 368 students, and force as many as 5052012 student. The sampling technique used is the purposive sampling technique. Tool collecting data using a detailed questionnaire with Likert scale, which consists of a detailed questionnaire for academic procrastination and academic efficacy. While the achievement of student learning is measured based on the CPI. The analysis used in this study is the technique of correlation of Product Moment with the help of SPSS Version 18.0. The first hypothesis test results showed that the relationship between academic procrastination and academic achievement, known (r) correlation coefficient between academic procrastination and academic achievement of 0.015 with $p 0.890>0.05$ negative correlation, direction and with the guidelines of the wear level of significance of 5\%, obtained $p$ $0.890>0.0 .5$ then correlation between academic procrastination and academic achievement is declared not significant. The second hypothesis test results showed a relationship between academic efficacy with academic achievement, known coefficient of correlation $(r)$ between academic efficacy and academic achievement $-0.0040 .970>$ with $p 0.05$, direction correlation negative and wear guidelines significance level 5\%, obtained p $0.970>0.05$ then correlation between academic efficacy with academic achievement is expressed is not significant. While the third hypothesis test results showed the absence of significant correlation between academic procrastination and academic efficacy simultaneously toward academic achievement with the retrieved $R$ square (coefficient of determination) of 0000, and the coefficient correlation of 0.015 with $0.990>p$ 0.05. Further, it is known from the $F_{\text {count }}$ of 0.010 of $F_{\text {table }}$ of 3.10 , so that $H_{0}$ is accepted and Ha was rejected.
\end{abstract}

Keywords: Correlation, Efficacy, Procrastination, Achievement, Academic

\section{Article Info}




\section{PENDAHULUAN}

Kemajuan masyarakat dalam Ilmu Pengetahuan,Teknologi dan Seni (IPTEKS) dewasa ini, tidak mungkin dapat dicapai tanpa kehadiran institusi pendidikan sebagai organisasi yang menyelenggarakan pendidikan secara formal. Proses pendidikan yang berlangsung mempunyai ukuran standarisasi dalam menilai sejauh mana pengetahuan dan keterampilan mahasiswa tercapai (Tilaar, 2006).

Mahasiswa dalam kaitannya dengan dunia pendidikan, merupakan salah satu substansi yang perlu diperhatikan, karena mahasiswa merupakan penerjemah terhadap dinamika pengetahuan, dan melaksanakan tugas untuk mendalami ilmu pengetahuan tersebut. (Harahap, 2006). Mahasiswa secara umum merupakan subyek yang memiliki potensi untuk mengembangkan pola kehidupannya, dan sekaligus menjadi obyek dalam keseluruhan bentuk aktivitas dan kreativitasnya, sehingga diharapkan mampu menunjukkan kualitas yang dimilikinya.

Kualitas mahasiswa dapat dilihat dari prestasi akademik yang dicapainya. Prestasi akademik merupakan perubahan dalam hal kecakapan tingkah laku ataupun kemampuan yang dapat bertambah selama beberapa waktu, dan yang tidak disebabkan oleh proses pertumbuhan, tetapi adanya situasi belajar. Sehingga dipandang sebagai bukti usaha yang diperoleh mahasiswa (Sobur, 2006).

Banyak studi yang telah melaporkan bahwa beberapa faktor yang secara positif dan negatif mempengaruhi prestasi akademik diantara para mahasiswa, seperti menghabiskan waktu dengan mengerjakan tugas-tugas, motivasi, kebiasaan belajar, stress, menunda-nunda pekerjaan, efficacy, burnout, self-esteem, dan sebagainya (Balkis \& Duru, 2009; Klassen, Krawchuk \& Rajani, 2008; Crede \& Kuncel, 2008).
Steel (Kartadinata \& Sia, 2008), berpendapat bahwa prokrastinasi adalah "to voluntarity delay an intended course of action despite expecting to be worse-off for the delay". Sedangkan menurut Senecal, Julian, dan Guay (Balkis, 2011), prokrastinasi akademik dapat didefinisikan as an irrational tendency to delay at the beginning or completion of an academic test. Dari dua definisi yang telah dikemukakan menunjukkan bahwa prokrastinasi akademik merupakan suatu bentuk kesengajaan untuk menundanunda pekerjaan akademik baik pada saat memulai ataupun menyelesaikannya walaupan mengetahui bahwa penundaan dapat menghasilkan dampak yang buruk. Dampak dari penundaan tersebut adalah menurunnya prestasi akademik. Hal ini didukung oleh penelitian Balkis \& Duru (2009), Ozer, Demir \& Ferrari (2009), yang menunjukkan bahwa procrastination is related to poor academic performance. Laporan BBC News Megazine (27 Agustus 2012), sebagaimana yang dinyatakan oleh Steel dari The Haskayne School of Business at the University of Calgary, penulis The Procrastination Equation, yang telah melakukan penelitian yang luas di dalam topik ini, menemukan bahwa 95\% dari kita melakukan prokrastinasi. Sedangkan penelitian Ferrari dariDePaul University Chicago, penulis Still Procrastinating? The No Regrets Guide to Getting It Done, yang telah menemukan bahwa $20 \%$ populasi dunia adalah prokrastinasi kronis, menyulitkan hidup mereka, dan mungkin memperpendeknya, dengan tidak putus-putusnya menunda dan menghindari tugas-tugas. Lebih lanjut penelitian yang dilakukan oleh Akinsola, Tella dan Tella (2007) terhadap prestasi matematika mahasiswa University Ibadan dan University Lagos, Nigeria, menunjukkan adanya korelasi yang signifikan antara prokrastinasi akademik dengan prestasi akademik di dalam mata pelajaran matematika. Namun, penelitian 
Keqiao (2010) yang dilakukan terhadap mahasiswa Chinese University memberikan hasil bahwa ada hubungan yang negatif signifikan dengan prestasi akademik. Hasil yang sama terjadi juga pada penelitian dilakukan oleh Kartadinata \& Tjundjing (Mayasari, Mustami'ah \& Warni, 2010) di salah satu Perguruan Tinggi Surabaya terdapat 95\% dari angket yang disebarkan pada 60 subyek mahasiswa mengatakan bahwa pernah melakukan prokrastinasi. Alasan terbesar yang membuat mahasiswa tersebut membuat prokrastinasi adalah rasa malas mengerjakan tugas $(42 \%)$ dan banyak tugas lain yang harus dilakukan $(25 \%)$.

Secara singkat, penelitian-penelitian tersebut sedang mengindikasikan bahwa prokrastinasi adalah perilaku bermasalah yang dialami secara luas diantara mahasiswa sebagai perilaku yang memiliki pengaruh negatif terhadap prestasi akademik. Dukungan lainnya yang menyatakan adanya hubungan yang negatif dan signifikan antara prokrastinasi akademik dengan prestasi akademik berasal dari hasil penelitian Amaliah (2011) terhadap siswa kelas XI SMA Negeri 1 Malang.

Faktor penting lain yang mempengaruhi prestasi akademik adalah selfefficacy. Park dan Kim (2006), menyebutkan efikasi diri sangat penting bagi pelajar untuk mengontrol motivasi mencapai harapanharapan akademik. Efikasi diri akademik jika disertai dengan tujuan-tujuan yang spesifik dan pemahaman mengenai prestasi akademik, maka akan menjadi penentu suksesnya perilaku akademik di masa yang akan datang (Bandura dalam Alwisol, 2004). Pemahaman ini menggambarkan bahwa efikasi diri akademik dapat menjadi suatu sumber daya yang sangat penting bagi pengembangan diri melalui pilihan aktivitas mahasiswa (Schunk dalam Santrock, 2008). Zimmermen (Balkis, 2011), mendefinisikan efikasi akademik as personal judgments of one's capabilities to organise and execute courses of action to attain designated types of educational performances. Melalui kedua definisi ini dapat disimpulkan bahwa efficacy akademik menunjuk kepada pendirian atau keputusan seseorang berkaitan dengan kapabilitasnya didalam mengorgansasikan dan melaksanakan serangkaian tugas-tugas akademik untuk mencapai kinerja akademik yang telah dirancang. Para peneliti telah menyediakan bukti bahwa efikasi diri akademik sebagai faktor penting yang mempengaruhi prestasi akademik (Adeyamo, 2007; Klassen, Krawchuck \& Rajani, 2008). Hasil penelitian Tenaw (2013) terhadap mahasiswa Analytical Chemistry I (ACI) di Debre Markos of Teacher Education (DMCTE) menunjukkan bahwa adanya hubungan yang signifikan antara selfefficacy dan prestasi akademik. Lebih lanjut, hasil penelitian Reniati (2009), menemukan bahwa ada hubungan yang positif dan sangat signifikan antara efikasi diri dengan prestasi akademik pada mahasiswa Universitas Negeri Malang. Senada dengan itu, penelitian Motlagh, Amrai, Yazdani, Abderahim, dan Souri (2011), menunjukkan bahwa self efficacy adalah faktor yang dapat dipertimbangkan sebagai prediktor terhadap prestasi akademik. Akan tetapi, ada juga hasil penelitian yang menunjukkan kontradiksi. Hasil penelitian yang dimaksudkan adalah penelitian dari Nurhasnah (2005), menunjukkan bahwa tidak ada hubungan yang signifikan antara self efficacy dengan indeks prestasi keberhasilan belajar pada mahasiswa Perguruan Tinggi Kedinasan Akamigas.

Selain hasil penelitian secara parsial hubungan antara prokrastinasi akademik dengan prestasi akademik, efikasi akademik dan prestasi akademik, Balkis (2011) telah melakukan penelitian dengan melihat pada peran efikasi akademik sebagai variabel mediator dan moderator dalam hubungan antara prokrastinasi akademik dengan prestasi akademik. Dalam penelitian ini Balkis (2011) 
menunjukkan bahwa mahasiswa dengan tingkat prokrastinasi akademik yang tinggi mereka memiliki tingkat self-efficacy yang rendah dan prestasi akademik yang jelek, dan mahasiswa dengan tingkat self-efficacy tinggi memiliki tingkat prokrastinasi akademik rendah dan tingkat prestasi akademik yang lebih tinggi. Lebih tepatnya hasil penelitian Balkis (2011) adalah sebagai berikut: academic effucacy has partial mediator role in relaion to the academic procrastination and reported academic achievement. Results also showed that academic-efficacy moderate relationship between academic procrastination and reported academic achievement by raising reported academic achievement and reducing academic procrastination.

Untuk mengetahui gambaran awal mengenai prokrastinasi akademik dan efikasi akademik mahasiswa Program Bimbingan Konseling Fakultas Keguruan dan Ilmu Pendidikan Universitas PGRI NTT, maka peneliti melakukan penelitian pendahuluan. Khusus untuk variabel prokrastinasi, pertanyaan wawancara tidak terstruktur diadopsi dan dimodifikasi sesuai dengan kepentingan penelitian ini dari Procrastination Assessment Scale for Student (PASS), yang terdiri dari enam area akademik (Solomon \& Rothblum, 1984). Sedangkan variabel efikasi diri, pertanyaan diadopsi dan dimodifikasi sesuai dengan kepentingan penelitian ini dari General self-Efficacy Scale, yang terdiri dari 10 item pertanyaan.(Born, Schwarzer \& Jerusalem, 1995). Hasil wawancara tidak struktur yang dilakukan terhadap 21 orang mahasiswa tersebut menunjukkan bahwa tingkat prokrastinasi akademik mahasiswa tinggi (19 orang), dan hanya 2 orang yang memiliki efikasi diri dalam kaitanya dengan melaksanakan tugas-tugas akademik.

Berdasarkan uraian permasalahan dari aras empirik dan teoritis dalam hal ini adanya kontradiksi hasil penelitian terdahulu serta peran variabel efikasi akademik sebagai mediator dan moderator terhadap hubungan antara prokrastinasi akademik dengan prestasi akademik, maka penelitian ini bertujuan untuk menginvestigasi dan mengetahui apakah ada hubungan yang positif dan signifikan antara efikasi akademik dan prokrastinasi akademik dengan prestasi akademik.

\section{TINJAUAN PUSTAKA \\ Prestasi Akademik}

Pengertian Prestasi Akademik

Prestasi akademik merupakan salah satu determinan dari keberhasilan hidup. Menurut Dauluta dan Nuthanap (dalam Calaguas, 2012), academic achievement serves as a key criterion in order to judge student's true potentials and capabilities. Lebih lanjut Dauluta dan Nuthanap (Calaguas, 2012) academic achievement has been one of the most important goals of the educational process. Jadi, prestasi akademik memiliki peran yang penting didalam meningkatkan atau menyakinkan kualitas, karena tanpa prestasi akademik lulusan yang dihasilkan sedang-sedang saja.

Faktor-faktor yang Mempengaruhi Prestasi Akademik

Nuthana (2007) mengemukakan tentang faktor-faktor yang mempengaruhi prestasi akademik, yaitu study habit (lingkungan rumah dan rencana kerja, kebiasaan membaca dan membuat catatan, perancanaan mata kuliah, kebiasaan konsentrasi, persiapan untuk ujian, kebiasan umum dan sikap, serta lingkungan universitas), self-concept (persepsi, keyakinan, perasaan, sikap, dan nilai yang mana individu memandang dirinya sendiri), socio economic status (posisi seseorang dalam komunitas, budaya, dan pasrtisipasinya dalam kelompok), dan gender. Sedangkan Soemanto (2006) menambahkan dua faktor lain, yaitu locus of control dan kecemasan yang dialami. 


\section{Ciri-ciri Individu yang Berprestasi}

Sahputra (2009) menyatakan bahwa ciri individu yang memiliki keinginan berprestasi tinggi adalah individu yang memiliki standar berprestasi, memiliki tanggung jawab pribadi atas apa yang dilakukannya, individu lebih suka bekerja pada situasi dimana dirinya mendapat umpan balik sehingga dapat diketahui seberapa baik tugas yang telah dilakukannya, individu tidak menyukai keberhasilan yang bersifat kebetulan atau karena tindakan orang lain, individu lebih suka bekerja pada tugas yang tingkat kesulitannya menengah dan realistis dalam pencapain tujuannya, individu bersifat inovatif dimana dalam melakukan tugasnya selalu dengan cara yang berbeda, efisien dan lebih baik dari sebelumnya, dengan demikian individu merasa lebih dapat menerima kegagalan atas apa yang dilakukannya.

\section{Efikasi Akademik}

\section{Pengertian Efikasi Akademik}

Efikasi diri dapat diartikan sebagai keyakinan manusia akan kemampuan dirinya untuk melatih sejumlah ukuran pengendalian terhadap fungsi diri mereka dan kejadian di lingkungannya (Bandura dalam Feist \& Feist, 2006). Efikasi diri individu dalam akademik disebut efikasi diri akademik. Sehingga, efikasi diri akademik dapat didefinisikan sebagai keyakinan yang dimiliki seseorang tentang kemampuan atau kompetensinya untuk mengarahkan motivasi, kemampuan kognisi, dan mengambil tindakan yang diperlukan untuk mengerjakan tugas, mencapai tujuan, dan mengatasi tantangan akademik.

\section{Proses-proses yang Mengiringi Efikasi Akademik}

Bandura (1997) menyebutkan empat proses yang mengiringi efikasi diri, termasuk efikasi diri akademik, yaitu proses kognitif, motivasi, afeksi, dan seleksi.

\section{Sumber-sumber Efikasi Akademik}

Menurut Bandura (Feist \& Feist, 2006) efikasi diri akademik dibentuk, dikembangkan, atau diturunkan melalui satu atau kombinasi dari keempat sumber, yaitu pengalamanpengalaman tentang penguasaan, pemodelan sosial, persuasi sosial, dan kondisi fisik serta emosional individu.

\section{Prokrastinasi Akademik}

\section{Pengertian Prokrastinasi Akademik}

Prokrastinasi secara tipikal dapat didefinisikan sebagai suatu pengaturan sifat atau perilaku untuk menunda tugas-tugas pekerjaan atau membuat keputusan (Milgram, Haycock \& Kachgal dalam Sirin, 2011). Lebih lanjut Sirin (2011) menjelaskan bahwa apabila prokrastinasi dikaitkan dengan akademik (academic procrastination) maka akan meliputi tugas-tugas akademik, dan dapat dijelaskan sebagai penundaan tugas-tugas akademik karena beberapa alasan.

\section{Faktor-faktor yang Mempengaruhi Prokrastinasi Akademik}

Menurut Gufron, Nur \& Rini (2010), ada dua kategori faktor yang mempengaruhi prokrastinasi akademik, yaitu: faktor internal yang terdiri dari kondisi fisik individu dan kondisi psikologis individu, sedangkan faktor eksternal meliputi gaya pengasuhan orang tua dan kondisi lingkungan. Ferrari (Ilfiandra, 2010) menyatakan bahwa faktor yang paling dominan mempengaruhi prokrastinasi akademik yaitu fear of failure yang merupakan suatu ketakutan berlebihan untuk gagal dan menyebabkan mahasiswa melakukan prokrastinasi.

\section{METODE PENELITIAN}

\section{Jenis dan Lokasi Penelitian}

Penelitian ini merupakan penelitian eksplanasi yang bertujuan untuk memberi jawaban atas pertanyaan mengapa dengan menjelaskan alasan terjadinya suatu fenomena (Supramono \& Utami, 2004). Untuk menjawab pertanyaan mengapa, maka peneliti mencoba untuk melihat keterkaitan antara variabel, dimana keterkaitan yang dimaksud dalam penelitian ini adalah menguji hubungan (korelasi). 
Penelitian ini dilaksanakan di Program Studi Bimbingan Konseling Fakultas Keguruan dan Ilmu Pendidikan Universitas PGRI Nusa Tenggara Timur yang terletask Jl. Perintis Kemerdekaan III/40 Kota Baru, Kota Kupang-NTT.

Populasi, Sampel dan Teknik Pengambilan Sampel.

Populasi menunjuk pada keseluruhan unit atau individu dalam ruang lingkup yang ingin diteliti. Dalam penelitian ini, yang menjadi populasi adalah seluruh mahasiswa Program Studi Bimbingan Konseling Fakultas Keguruan dan Ilmu Pendidikan Universitas PGRI dari semester 2 sampai dengan semester 8, yang berjumlah 912 orang. Sedangkan sampel adalah sebagian dari jumlah karakteristik yang dimiliki oleh populasi dan apa yang dipelajari dari sampel itu (Sugiyono, 2002). Memakai rumor Yamane (1973), jumlah sampel yang akan diteliti adalah 92 orang. Teknik pengambilan sampel yang digunakan adalah purposive sampling yaitu teknik penentuan sampel dengan pertimbangan tertentu (Supramono \& Haryanto, 2005). Sehubungan dengan tujuan penelitian yaitu tentang prestasi akademik, maka sampel yang dipilih adalah mahasiswa yang sementara aktif mengikuti kuliah.

\section{Teknik Pengumpulan Data}

Metode pengumpulan data menggunakan metode survei dengan teknik kuesioner. Lebih lanjut, teknik kuesioner/ angket dimaksudkan untuk mengukur efikasi akademik dan prokrastinasi akademik. Teknik pengumpulan data untuk efikasi akademik diadaptasi dari Aitken Procrastination Inventory (API) yang terdiri dari 19 item. Inventory ini dikembangkan untuk membedakan antara prokrastinasi yang kronis dengan prokrastinasi yang tidak kronis diantara mahasiswa-mahasiswa perguruan tinggi.

Teknik pengumpulan data untuk efikasi akademik diadaptasi dari sub skala efikasi akademik dari Maslach Burnout
Inventory Student Survey yang digunakan untuk menilai efikasi akademik partisipan. Inventori ini terdiri dari 6 item.

\section{Tekhnik Pengukuran Data}

Metode untuk mengukur data yang digunakan adalah metode skala. Skala adalah alat untuk mengukur nilai, sikap, minat, perhatian motivasi, yang disusun dalam bentuk rentang nilai angka sesuai dengan kriteria yang dibuat peneliti (Sudjana, 2001). Untuk kuesioner, efikasi akademik dan prokrastinasi akademik menggunakan teknik pengukuran Skala Likert. Skala ini digunakan untuk mengukur sikap, pendapat dan persepsi seseorang atau sekelompok gejala sosial (Riduwan, 2002). Sedangkan untuk prestasi akademik menggunakan IPK mahasiswa.

Skala Likert merupakan instrumen yang umum digunakan untuk meminta responden agar memberikan respon terhadap beberapa pertanyaan atau pernyataan, dan hal ini sering digunakan dalam penelitian pendidikan (Sudjana, 2001). Bentuk pilihan responden dari kepuasan kerja, etos kerja dan kinerja guru adalah: Sangat Setuju (SS) diberi skor 5; Setuju (S) diberi skor 4; cukup setuju (CS) diberi 3; dan Tidak Setuju (TS) diberi skor 2; dan Sangat Tidak Setuju (STS) diberi skor 1 .

\section{Analisis Validitas dan Reliabilitas Item}

Uji validitas instrumen penelitian atau tingkat ketepatan instrumen penelitian adalah tingkat kemampuan instrumen penelitian untuk mengungkapkan data sesuai dengan masalah yang hendak diungkapkannya. Validitas pengukuran berhubungan dengan kesesuaian dan kecermatan fungsi ukur dari alat yang digunakan.

Uji reliabilitas merupakan tingkat kebebasan dari random errors sehingga alat ukur yang digunakan dapat memberi hasil yang konsisten. Reliabilitas merupakan faktor kondisional bagi validitas tetapi data yang reliabel belum tentu valid. Jadi, reliabilitas menyangkut akurasi konsistensi, dan stabilitas 
alat ukur. Suatu kuesioner dikatakan handal jika jawaban seseorang terhadap pernyataan adalah konsisten atau stabil dari waktu ke waktu (Ghozali, 2001).

\section{Analisis Korelasi}

Furchan (Atmojo, 2009) menjelaskan bahwa analisis korelasi digunakan untuk menemukan ada tidaknya hubungan dan apabila ada, berapa eratnya serta berarti atau tidak hubungan antar variabel-variabel itu. Indeks-indeks statistik yang dapat menunjukkan arah (positif dan negatif) dan juga kekuatan suatu hubungan antar variabel disebut koefisien korelasi. Derajat koefisien korelasi dinyatakan dalam angka koefisien korelasi yang bergerak antara $-1,0$ sampai $+1,0$. Koefisien korelasi -1,0, menunjukkan adanya hubungan yang negatif secara sempurna, sedangkan nilai $+1,0$, menunjukkan adanya hubungan yang positif secara sempurna. Sedangkan jika nilainya 0 , menunjukkan bahwa dua variabel yang diteliti tidak terdapat hubungan sama sekali.

Sudjana (2001) menetapkan kriteria tinggi rendahnya hubungan dan kekuatan hubungan yang dilihat dari besar kecilnya indeks koefisien korelasi sebagai berikut:

$0,00<0,20=$ menunjukkan hubungan sangat rendah

$0,20-0,40=$ menunjukkan hubungan rendah $0,40-0,70=$ menunjukkan hubungan sedang dan cukup

$0,70-0,90=$ menunjukkan hubungan kuat $0,90-1,00=$ menunjukkan hubungan sangat kuat

Statistik untuk menguji korelasi antara variabel kepuasan kerja $\left(\mathrm{X}_{1}\right)$ dengan kinerja guru (Y) dan antara variabel etos kerja $\left(\mathrm{X}_{2}\right)$ dengan kinerja guru (Y) menggunakan teknik korelasi Product Moment dari Pearson dengan bantuan software SPSS 18.0. Handi (Atmojo, 2009) menjelaskan bahwa teknik ini dipilih berdasarkan tiga asumsi, yaitu: (1) Asumsi accidental, artinya bahwa pengambilan sampel dilakukan secara acak atau random; (2) asumsi normal distribution, artinya variabel yang akan dikorelasikan reratanya mengikuti sebaran normal; (3) asumsi homegenity of variance, artinya bahwa kelompok variansi antar kelompok yang satu dengan kelompok yang lain homogen.

\section{HASIL DAN PEMBAHASAN \\ Hasil}

Karakteristik Responden

Berdasarkan kuesioner yang disebarkan kepada mahasiswa Program Studi Bimbingan dan Konseling Universitas PGRI NTT, diperoleh karakteristik responden mengenai jenis kelamin, usia, dan asal daerah. Berdasarkan deskripsi sampel penelitian dapat terlihat bahwa sampel penelitian ini terdiri dari 92 orang mahasiswa, terdiri dari 40 laki-laki (43\%) dan 52 perempuan $(57 \%)$. Hal ini berarti bahwa subjek penelitian berdasarkan jenis kelamin, perempuan lebih mendominasi prosentasenya daripada laki-laki. Persentase karakteristik kedua yaitu usia menunjukkan bahwa sebagian besar responden telah berusia 20-24 tahun yaitu sebanyak 62 responden (67\%). Data ini menunjukkan bahwa usia responden dapat dikategorikan masuk dalam tahap aktualisasi diri.

Berdasarkan asal daerah, tampak kebanyakan mahasisa Program Studi Bimbingan Konseling Universitas PGRI NTT berasal dari daerah, atau dengan kata lain berasal dari luar Kota Kupang, dimana prosentasinya terbanyak berasal dari Flores (27\%), Sumba (21\%), dan Timor Tengah Selatan (15\%).

Uji Validitas Instrumen Prokrastinasi Akademik

Dari hasil uji validitas 19 butir instrumen prokrastinasi akademik diperoleh 3 butir item yang memiliki nilai $r$ hitung $<0,3$ yaitu butir nomor $2(r=0,142), 8(r=0,270), 10$ $(r=-0,195)$, dan $(r=-0,202)$. Dengan demikian 3 butir nomor dinyatakan tidak valid dan 
dikeluarkan dari analisis. Butir item lainnya sebanyak 16 butir memiliki nilai $\mathrm{r}$ hitung paling rendah sebesar 0,338 (butir nomor 15) dan nilai $r$ hitung paling tinggi sebesar 0,684 (butir nomor 12). Dengan demikian, 16 butir instrumen prokrastinasi akademik dinyatakan valid.

\section{Uji Instrumen Efikasi Akademik}

Dari hasil uji validitas 6 butir instrumen efikasi akademik diperoleh 6 butir item yang memiliki nilai $r$ hitung $>0,3$. Dari 6 butir instrumen, yang memiliki nilai $r$ hitung paling rendah 0,323 (butir nomor 2) dan paling tinggi 0,501 (butir nomor 5). Oleh karena, seluruh butir instrumen memiliki nilai $r$ hitung $>$ 0,3 maka ke-6 butir tersebut dinyatakan valid.

\section{Uji Reliabilitas Item}

Setelah pengujian validitas, maka tahap selanjutnya adalah pengujian reliabilitas. Uji reliabilitas mengindikasikan bahwa suatu instrumen tidak bias dan suatu instrumen handal diujikan pada waktu, tempat, dan orang yang berbeda-beda. Pengukuran reliabilitas instrumen penelitian dilakukan dengan menganalisis koefisien cronbach's alpha. Koefisien cronbach's alpha yang mendekati satu menandakan reliabilitas konsistensi yang tinggi. Umumnya, koefisien reliabilitas cronbach's alpha kurang dari 0,60 menandakan reliabilitas yang buruk. Reliabilitas yang dapat diterima berada diantara nilai 0,60-0,79 dan reliabilitas yang sangat tinggi adalah yang lebih dari 0,80 (Ghozali, 2001). Berikut Tabel 4.2 merupakan hasil pengujiannya.

Tabel 1. Ringkasan Uji Reliabilitas

\begin{tabular}{cccc}
\hline Variabel & $\begin{array}{c}\text { Koefisien } \\
\text { Alpha }\end{array}$ & Batas & Makna \\
\hline Prokrastinasi & 0,866 & 0,6 & Reliabel \\
\hline Efikasi & 0,674 & 0,6 & Reliabel \\
\hline
\end{tabular}

Berdasarkan hasil uji reliabilitas di atas, tampak seluruh variabel memiliki koefisien alpha cronbach lebih dari batas minimal yang ditetapkan. Koefisien alpha terendah terjadi pada variabel efikasi akademik dan koefisien alpha tertinggi terjadi pada variabel prokrastinasi akademik. Oleh karena koefisien alpha > 0,6 maka seluruh instrumen dinyatakan reliabel.

\section{Uji Normalitas}

Sebelum melakukan uji hipotesa menggunakan dua alat analisis statistik parametrik, maka akan dilakukan uji penormalan data memakai tes kolmogorofsmirnof terlebih dahulu. Tujuan dilakukannya tes penormalan data adalah untuk melihat apakah data yang digunakan sebagai sampel telah terdistribusi normal.

Berdasarkan output data uji normalitas Kolmogorov-Smirnov tersebut di atas, maka nilai masing-masing signifikan adalah: prokrastinasi akademik responden sebesar 0.271 efikasi akademik 0.274 ; dan prestasi akademik 0.126 . Ini berarti bahwa distribusi sebaran hasil pengukuran untuk variabel prokrastinasi $\left(\mathrm{X}_{1}\right)$, efikasi $\left(\mathrm{X}_{2}\right)$ dan prestasi akademik (Y) berdasar perhitungan peluang kesalahan $\mathrm{p}$ tersebut semuanya lebih besar dari 0.05 . Artinya variabel prokrastinasi akademik, efikasi akademik dan prestasi akademik berdistribusi normal, dengan demikian pengolahan data dapat dilanjutkan dengan analisis korelasi Person Product Moment.

\section{Uji Hipotesis \\ Pengujian Hipotesis Pertama $\left(\mathrm{H}_{1}\right)$}

Hipotesis pertama pada penelitian ini adalah: "terdapat hubungan yang tidak signifikan antara prokrastinasi akademik dengan prestasi akademik mahasiswa Program Studi Bimbingan Konseling Universitas PGRI NTT". Hipotesis tersebut diuji dengan menggunakan korelasi dengan hasil diketahui koefisien korelasi (r) antara prokrastinasi akademik prestasi akademik sebesar - 0.015 dengan $\mathrm{p}=0.890>0.05$, arah korelasinya negatif dan dengan pedoman memakai taraf signifikansi $5 \%$, didapatkan $\mathrm{p}=0.890>0.05$ maka korelasi antara prokrastinasi akademik dengan prestasi akademik dinyatakan tidak signifikan 


\section{Pengujian Hipotesis Kedua $\left(\mathbf{H}_{2}\right)$}

Hipotesis pertama pada penelitian ini adalah: "terdapat hubungan yang tidak signifikan antara efikasi akademik dengan prestasi akademik mahasiswa Program Studi Bimbingan Konseling Universitas PGRI NTT". Hipotesis tersebut diuji dengan menggunakan korelasi dengan hasil diketahui koefisien korelasi (r) antara efikasi akademik dengan prestasi akadmeik sebesar - 0.004 dengan $\mathrm{p}=0.970>0.05$, arah korelasinya negatif dan dengan pedoman memakai taraf signifikansi $5 \%$, didapatkan $\mathrm{p}=0.970>0.05$ maka korelasi antara efikasi akademik dengan prestasi akademik dinyatakan tidak signifikan.

\section{Pengujian Hipotesis Ketiga $\left(\mathrm{H}_{3}\right)$}

Hipotesis ketiga pada penelitian ini adalah: "terdapat hubungan yang tidak signifikan antara prokrastinasi akademik dan efikasi akademik secara bersama-sama dengan prestasi akademik mahasiwa Program Studi Bimbingan Konseling Universitas PGRI NTT". Hipotesis tersebut diuji dengan menggunakan korelasi dengan hasil sebagai berikut:

Tabel 2. Hasil Uji Anova Prokrastinasi dan Efikasi dengan Prestasi Akademik ANOVA $^{b}$

\begin{tabular}{|l|c|c|c|c|c|}
\hline Model & $\begin{array}{c}\text { Sum of } \\
\text { Squares }\end{array}$ & Df & $\begin{array}{c}\text { Mean } \\
\text { Square }\end{array}$ & F & Sig. \\
\hline 1 Regression & .001 & 2 & .000 & .010 & $.990^{\mathrm{a}}$ \\
Residual & 3.696 & 89 & .042 & & \\
Total & 3.697 & 91 & & & \\
\hline
\end{tabular}

a. Predictors: (Constant), efksi, prokras

b. Dependent Variable: ipk

Didasari Tabel 1.2. di atas diketahui bahwa hubungan secara bersama-sama antara prokrastinasi akademik dan efikasi akademik dengan prestasi akademik mahasiwa Program Studi Bimbingan Konseling Universitas PGRI NTT memiliki koefisien korelasi sebesar 0.015 dengan $p=0.990>0.05$. Lebih lanjut, hal ini diketahui dari $F_{\text {hitung }}$ sebesar 0.010 yang lebih kecil dari $\mathrm{F}_{\text {tabel }}$ sebesar 3.10 , sehingga $\mathrm{H}_{0}$ diterima dan $\mathrm{H}_{\mathrm{a}}$ ditolak.

\section{Pembahasan}

Hipotesis pertama pada penelitian ini adalah: "terdapat hubungan yang tidak signifikan antara prokrastinasi akademik dengan prestasi akademik mahasiswa Program Studi Bimbingan Konseling Universitas PGRI NTT”. Hasil penelitian membuktikan bahwa hipotesis 1 ini tidak signifikan. Hal ini bertentengan dengan hasil penelitian Setyawan, A. A. (2016) yang menunjukkan bahwa prokrastinasi berpengaruh positif terhadap prestasi belajar mahasiswa Prodi Pendidikan Akuntansi Fakultas Ekonomi Universitas Negeri Surabaya. Hasil penelitian ini juga tidak sejalan dengan hasil penelitian Anggraini, L. Y., \& Muti'ah, T. (2012) yang menemukan bahwa hubungan antara prokrastinasi dengan prestasi belajar adalah linier dan signifikan.

Penelitian ini juga menemukan bahwa korelasi antara efikasi akademik dengan prestasi akademik dinyatakan tidak signifikan. Hasil ini bertentangan dengan hasil penelitian Sigiro, O. N., Sigit, D. V., \& Komala, R. (2017). yang diperoleh dengan taraf signifikansi 0,05 menunjukkan bahwa terdapat hubungan antara efikasi diri dengan hasil belajar siswa $(r=0,742)$. Hasil ini juga bertentangan dengan hasil penelitian Ghufron, M. N., \& Suminta, R. R. (2013); Secara keseluruhan studi meta-analisis dari 14 penelitian yang dilakukan oleh Ghufron, M. N., \& Suminta, R. R. (2013) hasilnya bahwa efikasi diri mempunyai pengaruh terhadap hasil belajar matematika. Individu yang mempunyai efikasi diri yang tinggi akan mempunyai hasil belajar yang tinggi pula.

Mengapa demikian? Rupanya respon mahasiswa berbeda dalam menyikapi prokrastinasi, bisa positif dan bisa negatif; prokrastinasi sebagai perilaku bermasalah yang dialami mahasiswa bisa berpengaruh positif atau negatif terhadap prestasi akademik bisa jadi ditentukan oleh sikap mahasiswa 
Efikasi Akademik Dan Prokrastinasi Akademik Sebagai Prediktor ... | Zummy A. Dami \& Paula A. Loppies

yang bersangkutan; Jika disikapi positif, maka justru permasalahan yang dihadapi mahasiswa yang bersangkutan menjadi tantangan yang memicu kerja keras, tekun dan wajar jika justru berpengaruh positif terhadap hasil belajarnya.

Sejalan dengan individu-individu dengan efikasi diri yang tinggi, mereka lebih efektif dan gigih dalam menghadapi kesulitankesulitan dan kegagalan terutama yang berkaitan dengan menghadapi pemecahan masalah, mereka lebih mungkin untuk mencapai hasil yang bernilai dan memperoleh hasil belajar yang lebih baik. Hal ini dikarenakan individu dengan efikasi diri tinggi memiliki keyakinan yang kuat akan kemampuannya dalam mengatasi tantangan yang ada sedangkan individu dengan efikasi diri rendah cenderung mudah menyerah dan tidak yakin mampu mengerjakan pekerjaan yang menantang itu.

Walaupun begitu, hasil penelitian ini relevan dengan budaya organisasi dan kegiatan belajar mengajar, ada tidaknya efikasi diri dan prokrastinasi serta pengaruhnya terhadap hasil belajar, peran dosen tetap penting demi hasil belajar mahasiswa yang lebih baik.

\section{KESIMPULAN}

Tingkat prokrastinasi akademik dengan prestasi akademik mempunyai hubungan yang tidak signifikan. Selanjutnya, korelasi antara efikasi akademik dengan prestasi akademik dinyatakan tidak signifikan. Dengan demikian, besarnya sumbangan variabel prokrastinasi akademik dan efikasi akademik terhadap prestasi akademik tidak ada, sumbangan diberikan oleh variabel lain di luar prokrastinasi akademik dan efikasi akademik.

\section{DAFTAR PUSTAKA}

Adeyamo, D.A. 2007. Moderating Influence of Emational Intelligence on the Link between Academic Self-Efficacy and Achievement of University Students.
Psychology and Developing Societies. 19,2, 199-213

Akinsola, M. K., Tella, A., \& Tella A. 2007. Correlates of Academic Procrastination and Mathematics Achievement of University Undergraduate Students. Eurasia Journal of Mathematics, Science \& Technology Education. 3(4), 363-370

Alwisol. 2004. Psikologi Kepribadian. Malang: UMM Press

Anggraini, L. Y., \& Muti'ah, T. 2012. Prestasi Akademik Siswa Ditinjau Dari Prokrastinasi Dan Persepsi Anak Pada Pola Asuh Orang Tua di SMK Muhammadiyah 3 Yogyakarta. Jurnal Spirits, 3(1)

Atmojo, Y. E. 2009. Hubungan Antara Derajat Gaya Kepemimpinan Transformasional Kepala Sekolah dan Motivasi Berprestasi Guru dengan Kinerja Mengajar Guru (Studi Pada SMA Negeri 1 dan SMA Negeri 2 di Salatiga). Tesis. Salatiga: PPS-MMP Universitas Kristen Satya Wacana.

Balkis, M. \& Duru, E. 2009. Prevelance of Academic Procrastination Behavior Among Pre-Service Teachers, and Its Relationship with Demographics and Individual Preferences. Journal of Theory and Practice in Education. 5 (1), 18-32

Balkis, M. 2011. Academic Efficacy As a Mediator and Moderator Variable In the Realationship Between Academic Procrastination and Academic Achievement. Eurasian Journal of Educational Research, Issue 45, 1-16

Bandura, A. 1997. Self Efficacy: The Exercise of Control. New York: W. H. Freeman and Company. 
Kelola: Jurnal Manajemen Pendidikan, Vol. 5, No. 1, Januari-Juni 2018

Born, A., Schwarzer, \& Jerusalem, M. 1995. Indonesian Adoption of the General SelfEfficacy Scale, diakses Januari 18, 2012 dari

http://userpage.fuberlin.de/ health/indo nese.htm

Calaguas, G. M. 2012. Academic Achievement and School Ability: Implications ti Guidance and Counseling Programs. Journal of Arts, Science \& Commerce. Vol.- III, Issue 2(3), 49-55.

Crede, M., \& Kuncel, N.R. 2008. Study Habits, Skills, and Attitudes: The Third Pillar Supporting Collegiate Academic Performance. Perspective on Psychological Science. 3, 425-453

Feist, J. \& Feist, G.J. 2006. Theories of Personality, ed. VI. Yogyakarta: Pustaka Pelajar

Ghozali, I. 2001. Aplikasi analisis multivariate dengan program SPSS. Semarang: Badan Penerbit Universitas Diponegoro.

Ghufron, M. N. \& Rini R.S. 2010. Teori-teori Psikologi. Jogjakarta: Ar-ruzz media.

Ghufron, M. N., \& Suminta, R. R. 2013. Efikasi Diri dan Hasil Belajar Matematika: Meta-analisis. Buletin Psikologi, 21(1), 20.

Harahap, S. 2006. Penegakan Moral Akademik di dalam dan luar Kampus. Jakarta: Raja Grafindo.

Ilfiandra. 2010. Penanganan Prokrastinasi Akademik Siswa Sekolah Menengah Atas: Konsep dan aplikasi.Diakses 14 Januari, 2013 dari http://www.osun.org//journalprokrastina si.pdf

Kartadinata, I., \& Sia, T. 2008. Prokrastinasi Akademik dan Manajemen Waktu. Anima, Indonesian Psychological Journal. 23(2)110-112.
Keqiao, L. 2010. The Relationship Between Academic Procrastination and Academic Achievement in Chinese University Students. Dissertation. New York: State University of New York at Buffalo.

Kim, U. \& Park, Y. 2006. Factor Influencing Academic Achievement in Relational Cultures: The Role of Self-, Relational, and Collective Efficacy. In F. Pajares \& T. Urdan (ed.). The Self-Efficacy Beliefs of Adolescents. pp. 267-285. Connecticut: Information Age Publishing

Klassen, R.M., Krawchuk, L.L., \& Rajani, S. 2008. Academic Procrastination of Undergraduate: Low Self-Efficacy to Self-Regulate Predicts Higher Levels of Procrastination. Contemporary Educational Psychology. 33(4), 915931.

Mayasari, M. D., Mustami'ah, D., \& Warni, Weni, Endahing. 2010. Hubungan antara Persepsi Mahasiwa terhadap Metode Pengajaran Dosen dengan Kecenderungan Prokrastinasi Akademik pada Mahasiswa Fakultas Psikologi Universitas Hang Tuah Surabaya. Insan. Vol. 12 No. 02, 95-103

Motlagh, Shahrzad, Elahi, Amrai, Kourosh, Yazdani, Mohammad, Javad, Abderahim, Haitham, altaib, \& Souri, Hosein. (2011). The Relationship between Self-Efficacy and Academic Achievement in High School Students. Procedia Social and behavioral Sciences, 15, 765-768.

Nurhasnah. 2006. Hubungan Efikasi Diri dan Indeks Prestasi Keberhasilan Belajar. Forum Diklat. Vol. 13 No.03, 13-20.

Nuthana, P. G. 2007. Gender Analysis of Academic Achievement Among High School Students. Thesis. Dhaward: University of Agricultural Sciences. 
Efikasi Akademik Dan Prokrastinasi Akademik Sebagai Prediktor ... | Zummy A. Dami \& Paula A. Loppies

Ozer, B., Demir, A., \& Ferrari, J. 2009. Exploring Academic Procrastination Among Turkish Students: Possible Gender Differences in Perspective and Reasons. The Journal of Social Psychology. 149 (2), 241-257.

Riduwan. 2002. Skala Pengukuran Variabelvariabel Penelitian. Bandung: Alfabeta.

Santrock, J.W. 2008. Life-Span Development: Perkembangan Masa Hidup. Jakarta: Erlangga.

Setyawan, A. A. 2016. Pengaruh Gaya Belajar, Prokrastinasi dan Fasilitas Belajar Terhadap Prestasi Belajar Mahasiswa Prodi Pendidikan Akuntansi Fakultas Ekonomi Universitas Negeri Surabaya. Jurnal Pendidikan Akuntansi (JPAK), 4(3).

Sigiro, O. N., Sigit, D. V., \& Komala, R. 2017. Hubungan Efikasi Diri Dan Penalaran Ilmiah Dengan Hasil Belajar Biologi Siswa SMA. Biosfer: Jurnal Pendidikan Biologi, 10(2), 30-34.

Sirin, E. F. 2011. Academic Procrastination among Undergraduates Attending School of Physical of education and Sports: Role of General Procrastination, Academic Motivation and Academic Self-Efficacy. Educational Reseacrh and Reviews. Vol. 6(5)447-455.

Sobur, A. 2006. Psikologi Umum. Bandung: Pustaka Setia.

Solomon, L. J., \& Rothblum, E. D. 1984. Academic procrastination: Frequency and cognitive-behavioral correlates. Journal of Counseling Psychology, 31(4), 503-509.

Sudjana, N. 2001. Penelitian dan Penilaian Pendidikan. Bandung: Sina Baru Algensindo
Sugiyono. 2010. Metode Penelitian Pendidikan. Bandung: Alfabeta.

Supramono dan Haryanto, Jony, Oktavian. 2005. Desain Proposal Penelitian Studi Pemasaran. Yogyakarta: Andi Offset.

Supramono dan I. Utami. 2004. Desain Proposal Penelitian Akuntansi dan Keuangan. Yogyakarta: Andi Offset.

Tenaw, Yazachew, Alemu. 2013. Relationship Between Self-Efficacy, Academic Achievement and Gender in Analytical Chemistry at Debre Markos College of Teacher education. AJCE. 3(2)

Tillar, H. 2006. Standarisasi Pendidikan Nasional. Jakarta: Rineka Cipta. 